\title{
Enlarged cystic artery
}

\section{Francesk Mulita 주 , Nikolaos Benetatos, Ioannis Maroulis, Stylianos Germanos}

Department of General Surgery, University General Hospital of Patras Holy Mary the Help, Patras, Greece

\section{Correspondence to} Francesk Mulita; oknarfmulita@hotmail.com

Accepted 30 December 2020

\section{DESCRIPTION}

A 58-year-old woman presented to our clinic on a regular basis for laparoscopic cholecystectomy. The patient was scheduled for surgery as she complained of colicky abdominal pain on the right sight of the upper abdomen for the past 4 months. Her vital signs were unremarkable. On examination, there was no abdominal tenderness or distension, and no evidence of palpable mass. Bowel sounds were audible, and rectal examination was normal. Her routine blood tests, including haemogram, $\mathrm{C}$ reactive protein level, liver and renal function test, and serum amylase and lipase, were normal. Chest and abdominal radiography showed no abnormalities. An abdominal ultrasound was performed and revealed cholelithiasis with no other abnormalities.

During laparoscopy, the cystic artery was tortuous and significantly enlarged. An abnormal mass of the liver was also present, located at segment IV in continuation of gallbladder fundus (figure 1A-D). Control of the cystic artery was achieved with suture material. Gallbladder was resected en bloc with the hepatic lesion (figure 2). Instantaneous section was not performed. The patient did not have any postoperative complication and was discharged on the first postoperative day. Her final histopathology report was suggestive of inflammatory hepatocellular adenoma, which is the most common subtype and accounts for about $40 \%-50 \%$ of all hepatic adenomas.

Hepatocellular adenomas, also called hepatic adenomas, are rare benign lesions of the liver frequently associated with women using oral contraceptives. ${ }^{1}$ They are usually asymptomatic and found incidentally on imaging or during surgical
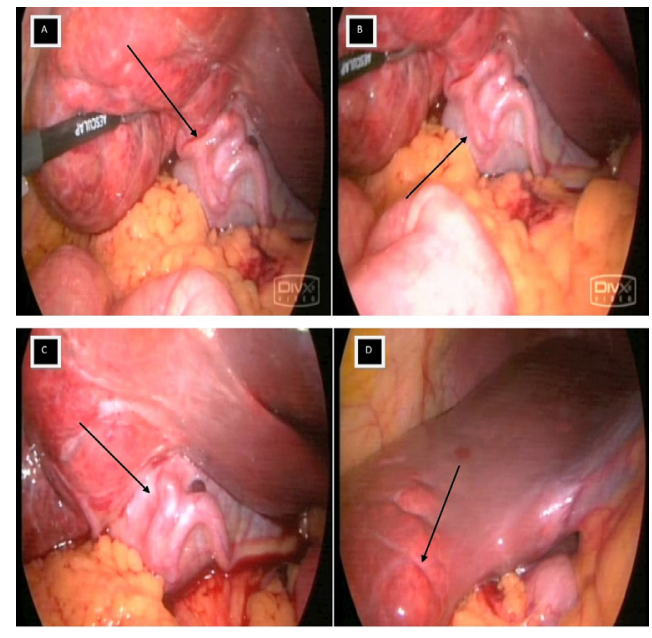

Figure $1 \quad(\mathrm{~A}-\mathrm{C})$ Enlarged cystic artery during laparoscopic cholecystectomy (arrow). (D) Adenoma located in hepatic segment $\mathrm{V}$ (arrow).

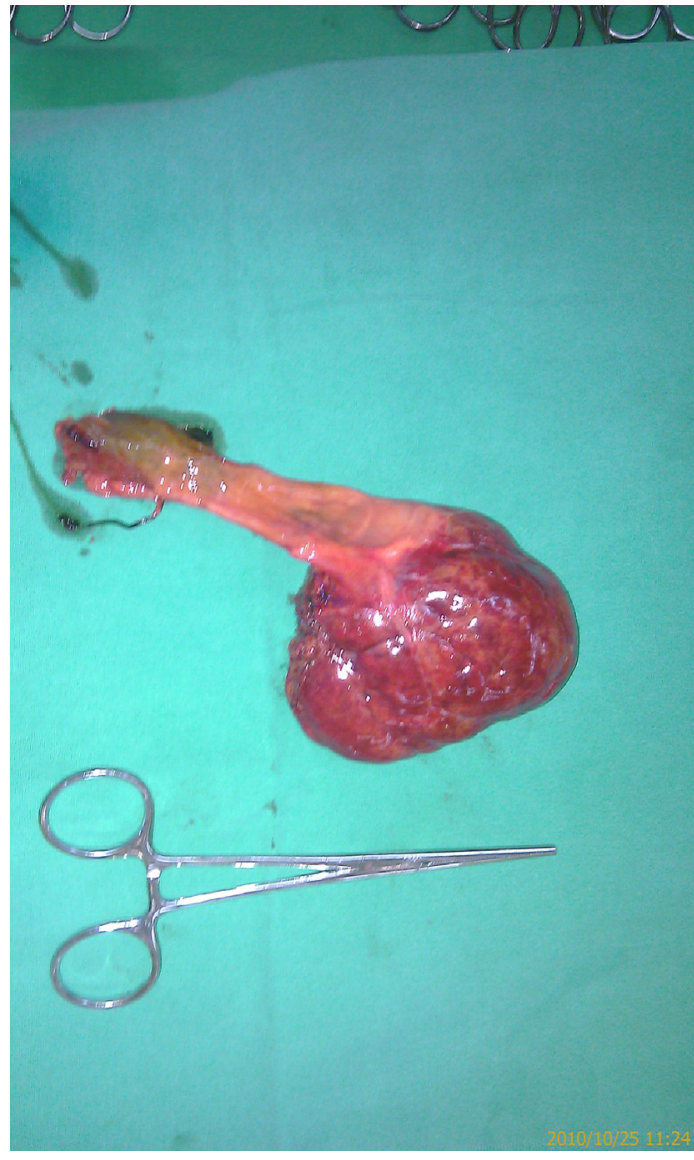

Figure 2 The specimen of the excised gallbladder en bloc with partial liver segment $\mathrm{V}$ and cystic artery.

operations. ${ }^{2}$ Although these tumours are usually benign, they are associated with the risk of malignant transformation to hepatocellular carcinoma, particularly when the diameter of the adenoma is

\section{Learning points}

- Hepatocellular adenomas are rare tumours that are usually found incidentally on imaging or surgical operations.

- Although hepatic adenomas are benign tumours, there are many risk factors, such as the tumour's diameter, that increase the likelihood for malignancy. In addition, betacatenin-mutated hepatic adenomas have a higher risk of malignant transformation.

- Laparoscopic cholecystectomy can be a challenging procedure and surgeons must be trained with advanced laparoscopic skills to complete the operation with safety and effectiveness. 
greater than $5 \mathrm{~cm} .{ }^{3}$ Elective resection is the operation of choice in all men with hepatic adenomas and in women with adenomas greater than $5 \mathrm{~cm}^{4}$

In our case, a $5.5 \mathrm{~cm}$ hepatic adenoma was identified in histopathology. Laparoscopic cholecystectomy was performed with en bloc resection of partial liver segment $\mathrm{V}$, where the liver adenoma was located. The procedure was technically difficult, as there was an enlarged cystic artery. In our patient, malignancy had to be excluded, because according to literature, tumours induce coordinate growth of arteries and veins. ${ }^{5}$ In addition, it has been known for more than 100 years that tumour vessels are often of large size. ${ }^{6}$

Contributors FM and SG had the idea of the study. FM and SG prepared the manuscript. NB and IM critically revised the manuscript. All authors accepted the final version of the manuscript.

Funding The authors have not declared a specific grant for this research from any funding agency in the public, commercial or not-for-profit sectors.
Competing interests None declared.

Patient consent for publication Obtained.

Provenance and peer review Not commissioned; externally peer-reviewed.

\section{ORCID iD}

Francesk Mulita http://orcid.org/0000-0001-7198-2628

\section{REFERENCES}

1 Tsilimigras DI, Rahnemai-Azar AA, Ntanasis-Stathopoulos I, et al. Current approaches in the management of hepatic adenomas. J Gastrointest Surg 2019:23:199-209.

2 Thomeer MG, Broker M, Verheij J, et al. Hepatocellular adenoma: when and how to treat? update of current evidence. Therap Adv Gastroentero/ 2016;9:898-912.

3 Grazioli L, Olivetti L, Mazza G, et al. Mr imaging of hepatocellular adenomas and differential diagnosis dilemma. Int J Hepatol 2013;2013:1-20.

4 Fodor M, Primavesi F, Braunwarth $\mathrm{E}$, et al. Indications for liver surgery in benign tumours. Eur Surg 2018;50:125-31.

5 Ruddell A, Croft A, Kelly-Spratt K, et al. Tumors induce coordinate growth of artery, vein, and lymphatic vessel triads. BMC Cancer 2014;14:354.

6 Nagy JA, Chang S-H, Dvorak AM, et al. Why are tumour blood vessels abnormal and why is it important to know? Br J Cancer 2009;100:865-9.

Copyright 2021 BMJ Publishing Group. All rights reserved. For permission to reuse any of this content visit

https://www.bmj.com/company/products-services/rights-and-licensing/permissions/

BMJ Case Report Fellows may re-use this article for personal use and teaching without any further permission.

Become a Fellow of BMJ Case Reports today and you can:

- Submit as many cases as you like

- Enjoy fast sympathetic peer review and rapid publication of accepted articles

- Access all the published articles

Re-use any of the published material for personal use and teaching without further permission

\section{Customer Service}

If you have any further queries about your subscription, please contact our customer services team on +44 (0) 2071111105 or via email at support@bmj.com.

Visit casereports.bmj.com for more articles like this and to become a Fellow 